\title{
Adaptation pathways to cope with salinization in south-west coastal region of Bangladesh
}

\author{
$\underline{\text { Peerzadi Rumana Hossain }}^{1}$, Fulco Ludwig ${ }^{1}$ and Rik Leemans ${ }^{2}$
}

\begin{abstract}
Salinization in coastal regions of Bangladesh challenges sustainable development of different sectors like agriculture, forestry, fisheries, livestock, and health. Particularly its southwest region largely faces increased salinity risks because of its geographical location and environmental settings. This study analyzes the causes of salinity increase, their cascading impacts on different coastal systems, and their livelihood implications, and assesses potential coping measures through innovative adaptation pathways for the most affected coastal systems. These pathways integrate bottom-up and top-down perceptions in adaptation planning through a driverpressure-state-impact-response framework, multicriteria analysis, and adaptation turning point approaches. We surveyed 200 households and interviewed 20 key informants. We observed that household-level respondents' perceptions are more closely related to socioeconomic aspects than to the biophysical environmental aspects and focus on issue-based action. However, the key informants focus more on the biophysical changes and the large-scale measures. The developed framework shows that salinity increase is an interconnected process of climatic-social-ecological-economic systems in the coastal environment. It also shows that responses already taken, i.e., polders and shrimp farming, to cope with salinization have later become pressures, i.e., riverbed siltation, waterlogging, and intensive salinization, on the systems. In total, we identified six interconnected causes of salinity increase and 24 potential measures to address them. Also we distinguished three coastal systems, i.e., crop-agriculture, drinking water sources, and the Sundarbans mangrove, most affected by salinity increase. Finally we proposed 16 adaptation pathways for these coastal systems based on the multicriteria analysis and adaptation turning points of the potential measures.
\end{abstract}

Key Words: adaptation pathway; coastal systems; salinization

\section{INTRODUCTION}

Climate change impacts such as sea level rise, more frequent natural hazards, and sea water intrusion are considered as the major causes for salinity increase in the world's deltaic regions (Nicholls and Cazenave 2010). For instance, several studies found that the Mekong Delta (Renaud et al. 2015), the Nile Delta (El Barmelgy and Rasheed 2016), and the Ganges tidal floodplain (Rahman and Rahman 2015) face increasing salinity problems. As part of Ganges Delta, Bangladesh is experiencing similar problems, particularly in its southwest region (Khanom 2016). This exposed coastal region lies about 1.5 meters above mean sealevel and this makes it vulnerable to sea-level rise, inundation, and salt-water intrusion (Chowdhury 2009).

Recent research has shown that salt intrusion is rapidly increasing in the region. From 2000 to 2009, salt-water intrusion increased up to $15 \mathrm{~km}$ north of the coast because of sea-level rise, and currently in the dry season, salt-water intrudes up to $160 \mathrm{~km}$ inland on account of reduced upstream river flows (SRDI 2010). This salt intrusion has large impacts on both ecological and socioeconomic systems that provide essential social, economic, and ecosystem services. Hence, its highly diverse ecosystems, like the world's largest single tract of mangroves (the Sundarbans), wetlands (vast network of rivers of the Ganges-Brahmaputra tidal plains), and inlands (mostly crop-agriculture) have already started to be severely affected by this salinization (Rabbani et al. 2013, Rasel et al. 2013, Sarker et al. 2016). In addition, this salinization leads to extreme drinking water scarcity for about 6.2 million people (Abedin et al. 2014).
The general causes and impacts of increasing salinity at large regional scale are broadly recognized (e.g., Khan et al. 2011, Mahmuduzzaman et al. 2014). However, understanding local socioeconomic and biophysical conditions is often too incomplete to identify the intermingling causes of the salinity increase and its cascading impacts on different coastal systems for integrated and sustainable adaptation planning (Nandy et al. 2013). For instance, extensive shrimp farming on the southwest coast of Bangladesh has created a direct conflict with crop agriculture. Shrimp farming has not only damaged agriculture but also agroforestry, fisheries, livestock, and physical infrastructures (Nowreen et al. 2014). Most coastal development interventions have largely focused on structural protection measures like dams, embankments, polders through top-down approaches and have largely ignored the complex and dynamic social, ecological, and economic systems in the region (Ayers et al. 2014). Therefore, adaptation approaches are unlikely to be effective if not all parts of the environment, i.e., biophysical and socioeconomic, are taken into account while identifying potential measures (Füssel 2007). In addition to the infrastructural developments both upstream (the Farakka barrage) and downstream (polders and embankments), climate change and sea-level rise exacerbate the salinity increase. Climate change increased the frequency and severity of hydro-climatic extremes, such as cyclones, tidal surges, and floods (Penning-Rowsell et al. 2013).

Although salt intrusion clearly has increased over the last decade, future salt intrusion rates are highly uncertain because of 
unknowns in future climate change (Dessai and van der Sluijs 2008) and upstream developments. As a result, policy makers often struggle with where, when, and which different measures need to be implemented. To deal with such uncertain futures, adaptation pathways based on adaptation turning points have been developed (Wise et al. 2014). Such adaptation pathways support decision making under uncertain future conditions (Haasnoot et al. 2014). Adaptation pathways have been mainly used in developed countries to identify potential flood defence measures in the Netherlands (Haasnoot et al. 2013) and robust options for coastal natural resource management in Australia (Bosomworth et al. 2015). However, the approach is relatively new in developing countries, such as Bangladesh.

A saline environment has always been part of Bangladesh's southwest and local people have been living with salt for the last three decades. However, the recent excessive salinization and its unfavorable impacts have forced people to already take small scale adaptation measures, like cultivating salt tolerant crops, raising the plinth of the houses and tube-wells, afforestation, and rainwater harvesting. However, large scale initiatives have not yet been considered. Hence, to obtain greater benefits, i.e., food security, biodiversity conservation, environmental protection, and sustainable livelihood, large scale adaptation planning is now needed. In this context, the Bangladesh Climate Change Strategy and Action Plan (BCCSAP 2009) was created. Implementing this action plan fundamentally requires better identification of the causes of salinity increase and characterization of its impacts because local adaptation is highly context dependent. Therefore, individual communities and ecosystems may require different adaptation plans based on varying causes and impacts of salinization (Huq et al. 2015).

In the context of BCCSAP 2009 and the problems policy makers have with implementing timely adaptation measures under changing climatic and socioeconomic conditions, our aim was to develop adaptation pathways to cope with salinization in Bangladesh's southwest coastal region. To develop the adaptation pathways, we studied the interconnected causes of salinity increase, the social and natural systems affected by salinity increase, and how they are affected. We also identified potential adaptation measures along with their contribution and adaptation turning points to address the identified causes and most affected coastal systems.

\section{METHODS}

We focus on three districts (Fig. 1A) of Bangladesh's southwest coast, i.e., Khulna, Bagerhat, and Satkhira, in that people of these three districts are severely affected by salinity increase. In our previous studies, we looked into the biophysical changes in the coastal environments and the Sundarbans mangrove, and we found significant changes over the forest (Hossain, Ludwig, and Leemans, unpublished manuscript) and hydro-climatic variables due to climate change, climate-change induced problems, and reduced upstream river flow (Hossain, Ludwig, and Leemans, unpublished manuscript). Hence, we selected these three districts to study the causes and impacts of, and adaptation pathways to cope with, salinization through household surveys, key informant interviews, the driver-pressure-state-impact-response (DPSIR) framework, multicriteria analysis, and the adaptation pathway approach based on an adaptation turning point (Table 1).
Fig. 1. Study area.

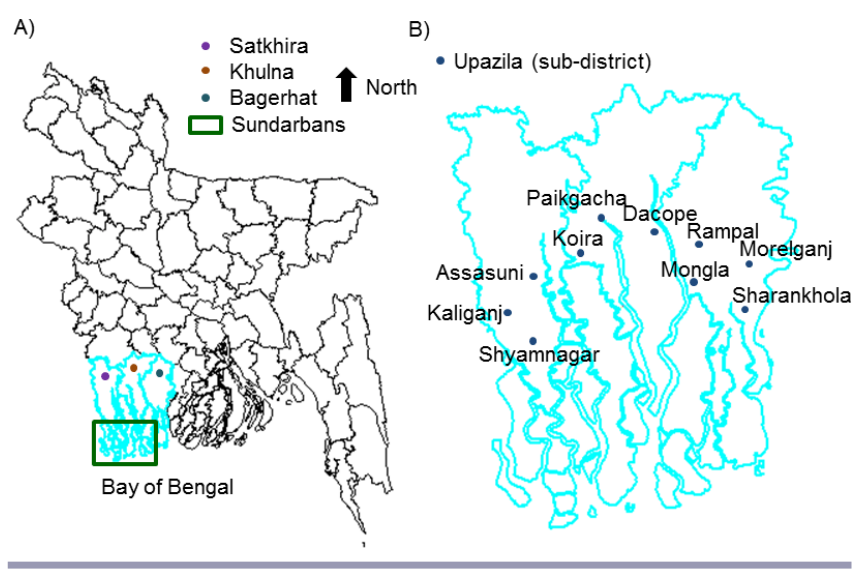

Table 1. Approaches used in this study along with their specific purpose.

\begin{tabular}{|c|c|c|}
\hline Approaches used & Description & Purpose \\
\hline $\begin{array}{l}\text { Household level } \\
\text { survey }\end{array}$ & $\begin{array}{l}\text { Local people's opinion } \\
\text { on a structured } \\
\text { questionnaire }\end{array}$ & $\begin{array}{l}\text { To get bottom-up } \\
\text { perceptions }\end{array}$ \\
\hline $\begin{array}{l}\text { Key informant } \\
\text { interview }\end{array}$ & $\begin{array}{l}\text { Observation of the } \\
\text { knowledgeable persons } \\
\text { on a structured } \\
\text { questionnaire }\end{array}$ & $\begin{array}{l}\text { To get top-down } \\
\text { perceptions }\end{array}$ \\
\hline DPSIR framework & $\begin{array}{l}\text { Integration of the } \\
\text { information on driver- } \\
\text { pressure-state-impact- } \\
\text { response }\end{array}$ & $\begin{array}{l}\text { To make social- } \\
\text { ecological-economic } \\
\text { connections }\end{array}$ \\
\hline $\begin{array}{l}\text { Multicriteria } \\
\text { analysis }\end{array}$ & $\begin{array}{l}\text { Analysis of a measure } \\
\text { under different criteria, } \\
\text { i.e., effectiveness, side } \\
\text { effects, cost, feasibility, } \\
\text { and uncertainty }\end{array}$ & $\begin{array}{l}\text { To identify the suitable } \\
\text { adaptation measures }\end{array}$ \\
\hline $\begin{array}{l}\text { Adaptation turning } \\
\text { point (ATP) }\end{array}$ & $\begin{array}{l}\text { A situation (for this } \\
\text { study, salinity) where a } \\
\text { measure's threshold is } \\
\text { reached }\end{array}$ & $\begin{array}{l}\text { To develop an } \\
\text { adaptation pathway }\end{array}$ \\
\hline Adaptation pathway & $\begin{array}{l}\text { A set of measures that } \\
\text { can be implemented } \\
\text { gradually depending on } \\
\text { the ATP }\end{array}$ & $\begin{array}{l}\text { To develop large scale } \\
\text { adaptation plan }\end{array}$ \\
\hline
\end{tabular}

As part of our bottom-up approach, 200 households through simple random sampling from 10 selected upazilas (subunits of a district) based on nearness to the coast (Fig. 1B) of three abovementioned districts were surveyed during December 2015 and January 2016 with a structured questionnaire. This questionnaire was designed to gather information on respondents' socioeconomic status along with their views on salinization, affected livelihoods and coastal systems, ways of being affected, and finally to obtain their opinion on potential (i.e., short-, medium-, long-term) measures that consider their own perceived risks along with adaptation turning points (salinity in parts per thousand [ppt]) and expected contributions to the particular system. 
The household survey resulted in too little information on midand long-term adaptation measures and potential adaptation turning points. To fill this gap, 20 key informants from different government and nongovernment organizations, universities, and research institutes (Fig. 2) were interviewed from July to August 2017 to get top-down perceptions on the same issues. Key informants were selected from the water, agriculture, forestry, fisheries, environment, and planning sectors by systematic sampling based on their research and work experience. The DPSIR framework (Smeets and Weterings 1999) was used to integrate the information of local people's perceptions and key informants' opinion to determine connections among the climatic, social, ecological, and economic systems (Pinto et al. 2013).

Fig. 2. Categories of key informants from different organizations and institutes.

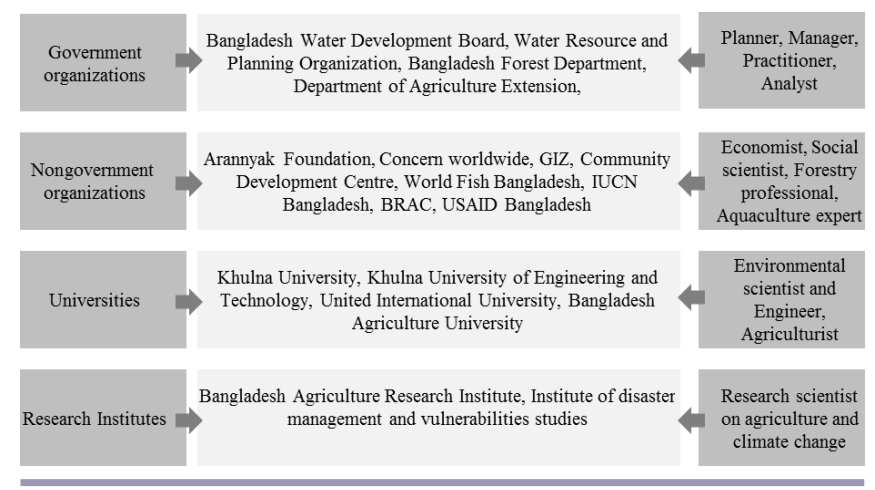

The assessment of potential adaptation measures identified by two different levels of respondents was done using a multicriteria analysis (L. H. Phi 2011, unpublished report). Measures were with regard to five different criteria: effectiveness, side effects, cost, feasibility, and uncertainty, which can be scored from being very negative (---) to being very positive $(+++)$. The criteria and their ranges were described to the respondents (Table 2) in the local language to score the measures. Each positive score was assumed to be valued by +1 and each negative score by -1 to rank them for identifying suitable measures.

Then the identified potential measures recommended by the household level respondents to address their own perceived causes of salinity increase were listed in combination with the results of the multicriteria analysis (Appendix 1). In addition, the potential set of measures recommended by the key informants to address the observed causes of salinity increase were recorded (Appendix 2 ). Based on the score of the multicriteria analysis, the best measures to address the main causes of salinity increase were selected. Because of a lack of responses from the household level respondents on long-term measures along with their tipping points and contributions for the most affected coastal systems, only key informants' observations were considered (Appendix 3). Because expected contributions of the identified adaptive measures interrelate, the main pressure on the particular system in combination with the major contribution of the identified measures to address that pressure were considered for developing adaptation pathways.
Table 2. Description with score card for the selected criteria of multicriteria analysis.

\begin{tabular}{|c|c|c|c|}
\hline \multirow[t]{2}{*}{ Criteria } & \multirow[t]{2}{*}{ Description } & \multicolumn{2}{|c|}{ Range } \\
\hline & & +++ & -- \\
\hline \multicolumn{4}{|c|}{ Effectiveness } \\
\hline & $\begin{array}{l}\text { Ability of a system to cope with } \\
\text { the consequences }\end{array}$ & $\begin{array}{l}\text { Highly } \\
\text { effective }\end{array}$ & $\begin{array}{c}\text { Not } \\
\text { effective }\end{array}$ \\
\hline \multicolumn{4}{|c|}{ Side effects } \\
\hline & $\begin{array}{l}\text { Secondary effects, both positive } \\
\text { and negative, that are not directly } \\
\text { related to the primary purpose }\end{array}$ & $\begin{array}{l}\text { Positive } \\
\text { effect }\end{array}$ & $\begin{array}{l}\text { Negative } \\
\text { effect }\end{array}$ \\
\hline \multicolumn{4}{|c|}{ 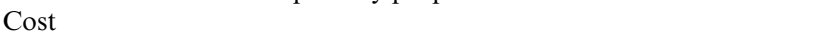 } \\
\hline & $\begin{array}{l}\text { Comprising construction/ } \\
\text { implementation cost, } \\
\text { maintenance cost, and } \\
\text { transaction costs }\end{array}$ & No cost & High cost \\
\hline \multicolumn{4}{|c|}{ Feasibility } \\
\hline & $\begin{array}{l}\text { Looks at the barriers that can } \\
\text { potentially hamper the } \\
\text { adaptation process. For example, } \\
\text { limited technical capacity, } \\
\text { economic strength, socio-cultural } \\
\text { acceptance, and potential } \\
\text { conflicts with current legal } \\
\text { settings }\end{array}$ & $\begin{array}{l}\text { Highly } \\
\text { feasible }\end{array}$ & Not feasible \\
\hline \multicolumn{4}{|c|}{ Uncertainty } \\
\hline & $\begin{array}{l}\text { Performance of a measure under } \\
\text { a wide range of changes in } \\
\text { climatic and socioeconomic } \\
\text { conditions }\end{array}$ & $\begin{array}{l}\text { No } \\
\text { uncertainty }\end{array}$ & $\begin{array}{l}\text { Highly } \\
\text { uncertain }\end{array}$ \\
\hline
\end{tabular}

Initially, the potential measures to address the dominant causes of salinity increase considering the top-down and bottom-up perceptions had been identified. Finally, the adaptation pathway maps for the most affected coastal systems were developed considering dominant cause of salinity increase in that particular system and results of the multicriteria analysis along with the tipping points for each of the potential measures suggested by the key informants. The Pathways Generator program was used to visualize the pathways maps (https://publicwiki.deltares.nl/ display/AP/Pathways+Generator). An example is given in Appendix 4 to facilitate interpretation of the developed pathway maps. It is a very new approach for Bangladesh, but will likely help to develop an adaptation plan for sustainability under climate change (Werners et al. 2013).

\section{RESULTS}

\section{Demographic and socioeconomic status of the household level respondents}

Most of the respondents of the survey were male, on average 35 years old, and illiterate (Table 3 ). We found nine different professions among the respondents. Agriculture was the dominant profession, followed by shrimp farming, and people dependent on other services derived from Sundarbans.

Dominant cause of salinity increase

Household respondents identified nine causes for the observed salinization (Figure 3A). In Satkhira, people perceived extensive shrimp farming as its main cause followed by siltation and polders. 
Also in Khulna, people identified extensive shrimp farming as the main cause followed by polders and waterlogging. However, in Bagerhat most respondents perceived that tidal water-level rise is the main cause behind salinity increase, followed by polders, waterlogging, and reduced upstream flow. Key informants, however, explained salinization by a combination of different processes (Figure 3B). They identified reduced upstream flow as the dominant cause in combination with polders and waterlogging, and closely followed by extensive shrimp farming and siltation.

Table 3. Demographic and socioeconomic status of the household level respondents.

\begin{tabular}{|c|c|c|c|c|}
\hline \multirow[t]{2}{*}{ Category } & \multirow[t]{2}{*}{ Characteristic } & \multicolumn{3}{|c|}{ Percentage $(\%)$} \\
\hline & & Khulna & Bagerhat & Satkhira \\
\hline \multirow[t]{2}{*}{ Gender } & Male & 62 & 70 & 83 \\
\hline & Female & 38 & 30 & 17 \\
\hline \multirow[t]{6}{*}{ Age } & $21-30$ & 22 & 7.5 & 15 \\
\hline & $31-40$ & 32 & 39 & 45 \\
\hline & $41-50$ & 30 & 26 & 18 \\
\hline & $51-60$ & 13 & 16 & 10 \\
\hline & $61-70$ & 3 & 11 & 7 \\
\hline & $71-80$ & 0 & 0 & 5 \\
\hline \multirow[t]{6}{*}{ Education } & Illiterate & 38 & 48 & 55 \\
\hline & Primary & 33 & 31 & 20 \\
\hline & Secondary & 23 & 18 & 15 \\
\hline & Higher Secondary & 2 & 4 & 2 \\
\hline & Graduate & 2 & 0 & 7 \\
\hline & Postgraduate & 2 & 0 & 2 \\
\hline \multirow[t]{9}{*}{ Profession } & Agri-crop farmer & 22 & 19 & 38 \\
\hline & Shrimp farmer & 14 & 14 & 13 \\
\hline & Fish farmer & 0 & 13 & 0 \\
\hline & Businessman & 5 & 11 & 0 \\
\hline & Daily laborer & 10 & 13 & 13 \\
\hline & Sundarbans dependent & 17 & 15 & 18 \\
\hline & Homestead agro-forestry & 13 & 11 & 12 \\
\hline & Crab farmer & 10 & 3 & 0 \\
\hline & $\begin{array}{l}\text { Livestock and poultry } \\
\text { farmer }\end{array}$ & 9 & 3 & 5 \\
\hline
\end{tabular}

Fig. 3. Perceived causes of salinity increase by different categories of respondents.

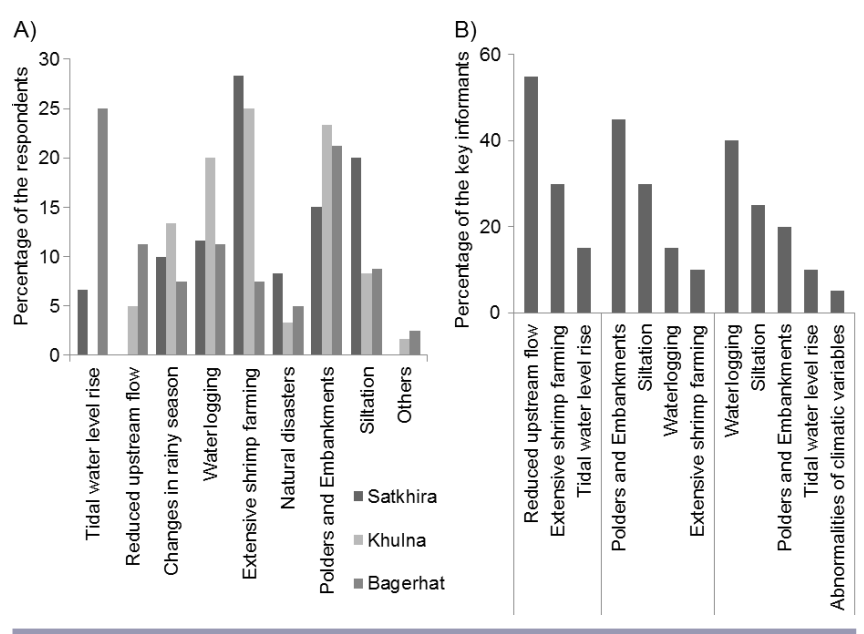

\section{Coastal systems affected by salinity increase}

Household respondents identified seven coastal systems that are affected by salinity increase (Fig. 4A). Almost half of the people in Satkhira, Khulna, and Bagerhat and most key informants (Fig. 4B) thought that crops were affected most. Experts identified similar vulnerabilities but eliminated aquaculture. Also most articulated was crop-agriculture. However, experts also indicated Sundarbans mangrove as the second most affected coastal system while the household respondents highlighted drinking water sources and health.

Fig. 4. Coastal systems most affected by salinity increase in southwest region.
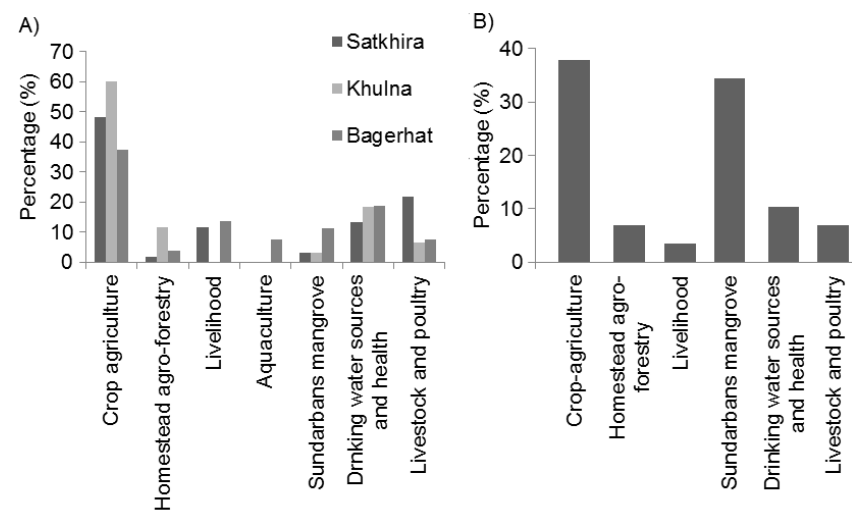

\section{Coastal communities affected by salinity increase}

Household respondents identified five different communities that are affected by salinity increase (Fig. 5A). Crop farmers were the most severely affected coastal communities followed by Sundarbans dependent communities. On the other hand, experts identified only three communities that were affected by salinization (Fig. 5B). More than half of the experts indicated the Sundarbans dependent people as the most affected communities followed by landless agri-laborers and crop farmers.

Fig. 5. Coastal communities most affected by salinity increase.

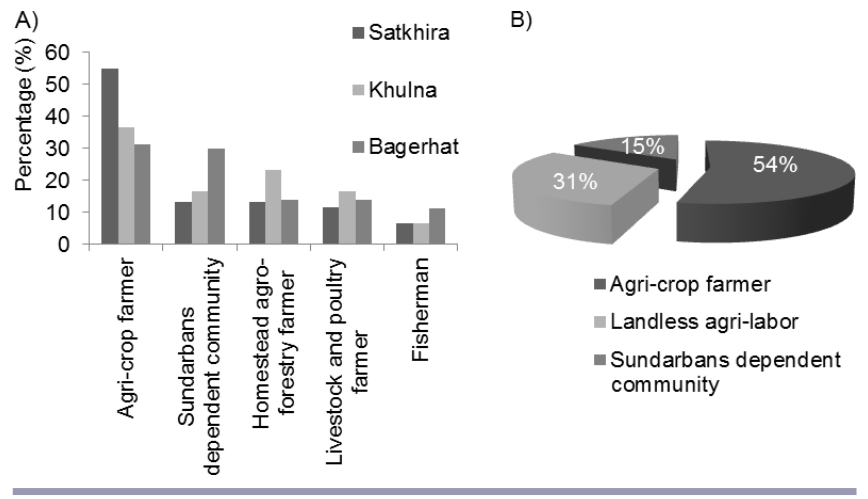

\section{Ways of being affected}

Both respondents identified similar effects on different coastal systems (Table 4). Crop agriculture was affected by degrading of soil quality. This results in less production and profit, land use changes, mostly shifts from crop agriculture to shrimp farming, 
Table 4. Observed effects of salinity increase by different categories of respondents.

\begin{tabular}{|c|c|c|}
\hline \multirow[t]{2}{*}{ Systems affected } & \multicolumn{2}{|c|}{ Ways of being affected } \\
\hline & $\begin{array}{l}\text { Household level respondents } \\
\text { (local people) }\end{array}$ & $\begin{array}{l}\text { Key informants } \\
\text { (Experts/resource persons) }\end{array}$ \\
\hline Crop-agriculture & $\begin{array}{l}\text { Reduced soil fertility } \\
\text { Less production and profit } \\
\text { Land use change (mostly crop-agriculture to shrimp) } \\
\text { Loss of agri-lands }\end{array}$ & $\begin{array}{l}\text { Degradation of soil quality } \\
\text { Less production } \\
\text { Uncertainty } \\
\text { Change in agriculture pattern } \\
\text { Food insecurity }\end{array}$ \\
\hline Homestead agro-forestry & No or less production & $\begin{array}{l}\text { No or less production } \\
\text { Reduction in homestead tree coverage }\end{array}$ \\
\hline Livelihood & Livelihood loss/change & $\begin{array}{l}\text { Livelihood change } \\
\text { Unemployment } \\
\text { Migration }\end{array}$ \\
\hline Aquaculture & Threatened local fresh water fish species & \\
\hline Sundarbans mangrove & $\begin{array}{l}\text { Lack of healthy trees } \\
\text { Thin forest/reduced forest cover } \\
\text { Less forest resources (both timber and nontimber) } \\
\text { Reduction in number of wild animals } \\
\text { Reduced amount of fish }\end{array}$ & $\begin{array}{l}\text { Vegetation change } \\
\text { Reduced tree growth } \\
\text { Invasion of top dying } \\
\text { Reduced stock density } \\
\text { Reduced biodiversity } \\
\text { Habitat degradation } \\
\text { Decreasing trend of fish resources }\end{array}$ \\
\hline Drinking water sources and health & $\begin{array}{l}\text { Drinking water crisis } \\
\text { Skin diseases } \\
\text { Diarrhoea and digestion problems } \\
\text { New born babies with different types of difficulties } \\
\text { Pregnancy problems }\end{array}$ & $\begin{array}{l}\text { Salinization of open and ground water sources } \\
\text { High blood pressure during pregnancy } \\
\text { Eclampsia }\end{array}$ \\
\hline Livestock and poultry & $\begin{array}{l}\text { Increased cost of rearing livestock and poultry } \\
\text { Fodder crisis }\end{array}$ & Fodder crisis \\
\hline
\end{tabular}

which causes loss of agri-lands and uncertainties ensuing from changes in agriculture pattern and food insecurity. The extent of homestead tree coverage was reduced gradually for lower productivity and in some cases no production at all. Local fish species were also threatened. The livestock and poultry sector were suffering from the fodder crisis, which contributes to increasing rearing cost. Sundarbans mangrove habitats degraded and this resulted in reduced forest growth and biodiversity, changes in vegetation, invasion of the undesirable top-dying disease and production of less forest resources, i.e., lack of heathy trees, reduction in number of wild animals, and decreasing fish species. Changes in or loss of livelihoods triggered unemployment and outmigration. Salinization of surface and ground water sources created a drinking water crisis. This generated different diseases and health problems like skin diseases, diarrhoea, digestion problems, and increase infant's diseases, i.e., anaemia and jaundice, and pregnancy complications, i.e., high blood pressure and eclampsia.

\section{DPSIR framework for salinity increase}

The developed DPSIR framework (Fig. 6) showed salinization drivers were not only related to biophysical changes in coastal environments but also with socioeconomic circumstances. Most of the identified pressures were man made and not environmental. The ecological, social, and economic state of different coastal systems, mostly crop agriculture, wetlands, and Sundarbans mangrove, were threatened by salinity increase. Threatened states of the these systems were creating conflicts among ecosystem, human health, and socioeconomic functions that eventually lead toward small- and large-scale measures, action plans, and policy responses. However, the responses were inadequate to address the identified pressures of salinity increase. Rather one of the responses, i.e., polders, has become the pressure for salinity increase initiating sedimentation on the river bed and waterlogging.

Potential measures to address the identified salinization drivers and pressures, along with their contribution and multicriteria analysis

Local people identified five short-term and two midterm measures to address salinization drivers and pressures. These measures should contribute to halting salinization of new lands, to maintaining the natural flow of the tidal rivers, to connecting the rivers with their flood plains, and to extending fresh water sources (Table 5). However, they did not identify any long-term measure. A multicriteria analysis of these measures (Appendix 1) shows that the local government's initiative to stop planned ingression of salt water is the most effective short-term measure and land zoning is identified as the most suitable midterm measure. On the other hand, key informants identified in total 18 potential measures to cope with salinization (Table 5). Among the identified measures, planned shrimp farming is the most suitable short-term measure followed by tidal river management as the midterm measure and long-term coastal land use zoning (Appendix 2).

\section{Adaptation pathways to cope with salinization for the most affected coastal systems}

Key informants identified 31 possible forms of different adaptation turning points from 7 to $20 \mathrm{ppt}$ for the most affected coastal systems (Appendix 3). Among these, 16 measures had 
Fig. 6. Interaction between society and coastal systems. (Here, SLR denotes sea-level rise; DPSIR: driverpressure-state-impact-response; NAPA: National Adaptation Programme of Action; and BCCSAP: Bangladesh Climate Change Strategy and Action Plan).

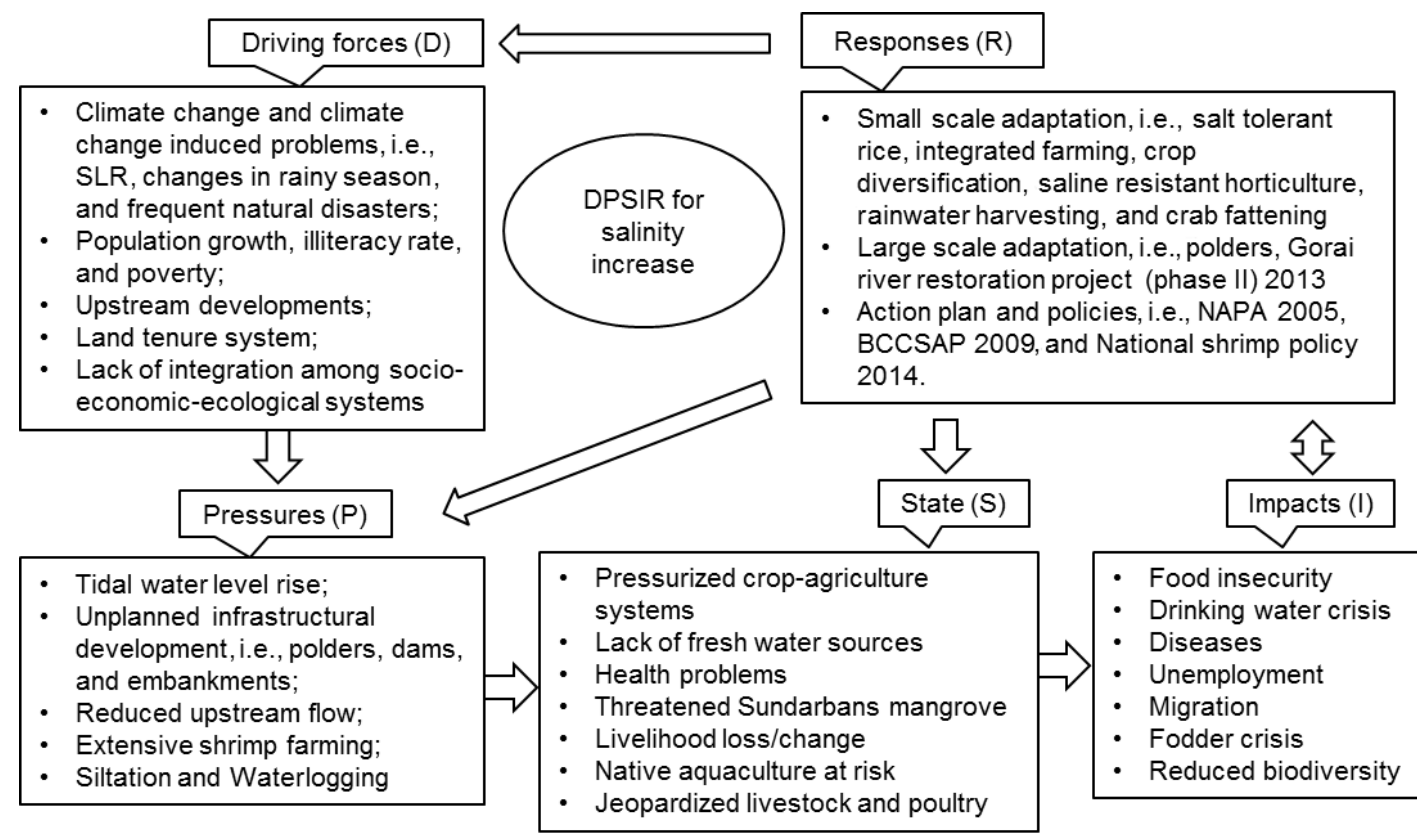

been filtered through a multicriteria analysis as the suitable measures. These are visualized in the adaptation pathway map (Fig. 7). For crop-agriculture, most suitable measures included crop diversification, adaptive agriculture, alternate cropping, and arable field management. A combined approach of crop diversification, arable field management, and alternate cropping was expected to sustain salinity levels until $12 \mathrm{ppt}$. Saline resistant horticulture was expected to sustain salinity levels until $15 \mathrm{ppt}$. However, for long-term adaptation planning, i.e., salinity levels up to $20 \mathrm{ppt}$, land zoning was the most suitable measure to promote agriculture, to improve farmers' socioeconomic conditions, and to resolve the conflicts between crop and shrimp farming. For drinking water sources, the adaptation pathway map showed six measures at different turning points. Among them rainwater harvesting, pond sand filter, pond excavation, and managed acquirer recharge were identified as the most suitable measures to be implemented in salinity ranges from 7 to $20 \mathrm{ppt}$. For Sundarbans, public awareness combined with strengthening the Bangladesh Forest Department, ban catching fish during dry season, and canal (re)-excavation were the potential measures to deal with salinity levels from 7 to $12 \mathrm{ppt}$. Periodic or scheduled (re)-excavation to mainly restore the Gorai River was the next adaptive measure for salinity levels up to $15 \mathrm{ppt}$. However, if salinity levels cross $15 \mathrm{ppt}$, tidal river management and a Ganges Barrage were the suitable measures. These adaptation measures were expected to assist in sediment management and ensure ecological flow for the downstream rivers during the lean period with salinity levels beyond $17 \mathrm{ppt}$.

\section{DISCUSSION}

We identified six major interconnected climatic-social-ecologicaleconomic issues responsible for salinity increases in the southwest of Bangladesh. However, perceptions and observations of two different levels of the respondents on different processes of salinity increase varied. Household-level respondents' perceptions were closely related to local land use changes such as shrimp farming and polders. Polders contributed to reducing floodplain storage that caused river bed sedimentation, serious waterlogging, and thus salinization (WARPO 2001). This process was enhanced by expanded trends of shrimp farming (Swapan and Gavin 2011). Conversely, key informants focused more on the large-scale biophysical changes such as reduced fresh water inflow in combination with sea-level rise. Currently, tidal-water level is rising at 10 to $12 \mathrm{~cm}$ per decade (Bhuiyan and Dutta 2012) and fresh water influx is reducing significantly during the dry season (Mirza 1998).

Although both levels of our respondents agree on the most affected coastal system, i.e., crop-agriculture, their second choice was different. Local people, who have been living with salt for years, were more concerned about health risks related to drinking water sources while key informants were more concerned about ecological importance of the Sundarbans mangrove. Considering the significance of the Sundarbans mangrove ecosystem, major livelihoods depending on crop agriculture, and basic need for drinking water, we developed separate adaptation pathways for these three coastal systems.

Salinity is likely to increase in the future but by how much is uncertain. Hence, our adaptation pathways clearly show which measures can be implemented to cope with different levels of salinity. Some of the current measures are suitable, if salt intensification remains limited. For example, rainwater harvesting is a traditional measure to supply drinking water. However, uncertainties associated with this practice are the 
Table 5. Potential set of measures and their contribution to address the observed causes of salinity increase.

\begin{tabular}{|c|c|c|c|c|c|c|c|}
\hline \multirow[t]{3}{*}{ Main causes } & \multicolumn{6}{|c|}{ Potential measures along with the score from multicriteria analysis in (.. ) } & \multirow{3}{*}{$\begin{array}{l}\text { Expected } \\
\text { Contributions }\end{array}$} \\
\hline & \multicolumn{2}{|c|}{ Short term } & \multicolumn{2}{|c|}{ Midterm } & \multicolumn{2}{|c|}{ Long term } & \\
\hline & $\begin{array}{l}\text { Household } \\
\text { respondents }\end{array}$ & Key informants & $\begin{array}{l}\text { Household } \\
\text { respondents }\end{array}$ & Key informants & $\begin{array}{l}\text { Household } \\
\text { respondents }\end{array}$ & Key informants & \\
\hline \multirow[t]{2}{*}{$\begin{array}{l}\text { Extensive } \\
\text { shrimp } \\
\text { farming }\end{array}$} & $\begin{array}{l}\text { Local government's } \\
\text { initiative to change } \\
\text { the leasing system } \\
\text { of khash lands (12) }\end{array}$ & $\begin{array}{l}\text { Planned shrimp } \\
\text { farming practice (14) }\end{array}$ & $\begin{array}{l}\text { Land zoning } \\
\text { (11) }\end{array}$ & $\begin{array}{l}\text { Designing land } \\
\text { management } \\
\text { practice }(5)\end{array}$ & & $\begin{array}{l}\text { Coastal land use } \\
\text { zoning (11) }\end{array}$ & $\begin{array}{l}\text { Discontinue } \\
\text { salinization of new } \\
\text { lands }\end{array}$ \\
\hline & & & & & & & $\begin{array}{l}\text { Offset salinization in } \\
\text { agri-lands }\end{array}$ \\
\hline \multirow[t]{2}{*}{$\begin{array}{l}\text { Unplanned } \\
\text { Infrastructural } \\
\text { development } \\
\text { and } \\
\text { waterlogging }\end{array}$} & $\begin{array}{l}\text { Operational sluice } \\
\text { gates of the } \\
\text { existing polders ( } 7)\end{array}$ & $\begin{array}{l}\text { Functional } \\
\text { management of the } \\
\text { existing polders (6) }\end{array}$ & $\begin{array}{l}\text { Outlaw } \\
\text { building of } \\
\text { unnecessary } \\
\text { dams on the } \\
\text { rivers (11) }\end{array}$ & $\begin{array}{l}\text { Planned } \\
\text { infrastructural } \\
\text { development in } \\
\text { water resource } \\
\text { management (5) }\end{array}$ & & $\begin{array}{l}\text { Integrated } \\
\text { management of } \\
\text { different } \\
\text { systems (3) }\end{array}$ & $\begin{array}{l}\text { Ensure the natural } \\
\text { flow of the tidal } \\
\text { rivers; }\end{array}$ \\
\hline & & & & & & & $\begin{array}{l}\text { Improve the } \\
\text { drainage systems }\end{array}$ \\
\hline \multirow[t]{2}{*}{ Siltation } & $\begin{array}{l}(\mathrm{Re}) \text {-Excavation of } \\
\text { silted rivers }(6)\end{array}$ & $\begin{array}{l}\text { Periodic/scheduled } \\
\text { (re)-excavation as a } \\
\text { regular exercise (5) }\end{array}$ & & $\begin{array}{l}\text { Tidal river } \\
\text { management (TRM) } \\
\text { along with sediment } \\
\text { management } \\
\text { practice (14) }\end{array}$ & & $\begin{array}{l}\text { Continuous } \\
\text { monitoring on } \\
\text { river flow and } \\
\text { sedimentation } \\
\text { rate (5) }\end{array}$ & $\begin{array}{l}\text { Make sure of the } \\
\text { connection of the } \\
\text { rivers with the flood } \\
\text { plain }\end{array}$ \\
\hline & & & & & & & $\begin{array}{l}\text { Liberate the natural } \\
\text { process of land } \\
\text { formation through } \\
\text { sedimentation }\end{array}$ \\
\hline \multirow[t]{2}{*}{$\begin{array}{l}\text { Tidal water } \\
\text { level rise }\end{array}$} & $\begin{array}{l}\text { River bank } \\
\text { protection (pilling) } \\
\text { (5) }\end{array}$ & $\begin{array}{l}\text { Strengthen and } \\
\text { heighten existing } \\
\text { embankments (3) }\end{array}$ & & $\begin{array}{l}\text { Planned } \\
\text { infrastructural } \\
\text { development (5) }\end{array}$ & & $\begin{array}{l}\text { Delta plan / } \\
\text { Integrated long- } \\
\text { term plan for } \\
\text { the coast }(8)\end{array}$ & $\begin{array}{l}\text { Reduce tidal } \\
\text { inundation and } \\
\text { resist land loss }\end{array}$ \\
\hline & & & & & & & $\begin{array}{l}\text { Integrate all the } \\
\text { interacting systems } \\
\text { of coastal region for } \\
\text { planned adaptation }\end{array}$ \\
\hline \multirow[t]{4}{*}{$\begin{array}{l}\text { Reduced } \\
\text { upstream flow }\end{array}$} & $\begin{array}{l}\text { Government } \\
\text { initiative to change } \\
\text { the leasing system } \\
\text { and use of Khash } \\
\text { lands (10) }\end{array}$ & $\begin{array}{l}\text { To be active in } \\
\text { transboundary } \\
\text { negotiation process } \\
\text { on water sharing ( } 3 \text { ) }\end{array}$ & & $\begin{array}{l}\text { Administrative unit } \\
\text { wide assessment on } \\
\text { demand of water for } \\
\text { different category (5) }\end{array}$ & & $\begin{array}{l}\text { Water budget } \\
\text { and allocation } \\
\text { plan (6) }\end{array}$ & $\begin{array}{l}\text { Extend storage of } \\
\text { rainwater harvesting }\end{array}$ \\
\hline & & $\begin{array}{l}\text { Develop upstream } \\
\text { water management } \\
\text { plan/strategy for dry } \\
\text { season (3) }\end{array}$ & & $\begin{array}{l}\text { Enforcement of } \\
\text { Water Act } 2013 \text { on } \\
\text { priority basis ( } 5 \text { ) }\end{array}$ & & $\begin{array}{l}\text { Ganges barrage } \\
\text { for sustainable } \\
\text { river flow (7) }\end{array}$ & $\begin{array}{l}\text { Create transparency } \\
\text { on water demand } \\
\text { and supply }\end{array}$ \\
\hline & & & & & & & $\begin{array}{l}\text { Increase fresh water } \\
\text { influx during dry } \\
\text { season }\end{array}$ \\
\hline & & & & & & & $\begin{array}{l}\text { Ensure sustainable } \\
\text { environmental flow }\end{array}$ \\
\hline
\end{tabular}

changed rainfall pattern, storage facilities, and future salt concentrations. Other suitable measures, i.e., pond excavation and pond sand filter, are related to surface water sources. However, these sources are exposed to rises in tidal water levels, floods, cyclones, and tidal surges. Therefore, these measures are probably unsustainable in the long run. Hence, mechanisms to recharge ground water resources need to be adopted to ensure long-term safe drinking water supply. According to the multicriteria analysis, managed aquifer recharge likely is the most suitable measure to ensure availability and quality of drinking water sources. In addition, such recharge also serves to control salt- water intrusion, prevent land subsidence, and sustain other coastal systems' functioning. However, aquifer conditions must be suitable and water sources need to be ensured. This measure is successfully implemented for coastal urban areas in Australia (Dillon et al. 2009).

Artificial water logging conditions for shrimp farming are also accelerating the salinization of fresh water resources through seepage and natural bleaching. Most of the khash lands, i.e., government owned fallow land, leased to shrimp farmers are located in the inland part of the coastal zone, which is topographically and hydrologically unsuitable for shrimp 
Fig. 7. Adaptation pathway map for the most affected coastal systems.

0 Transfer station to new action I Adaptation tipping point (ATP) of an action - Adaptation pathways

Managed acquifer recharge

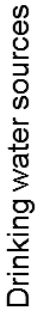

Pond sand filter

Current Situation

Pond excavation

Rain water harvesting

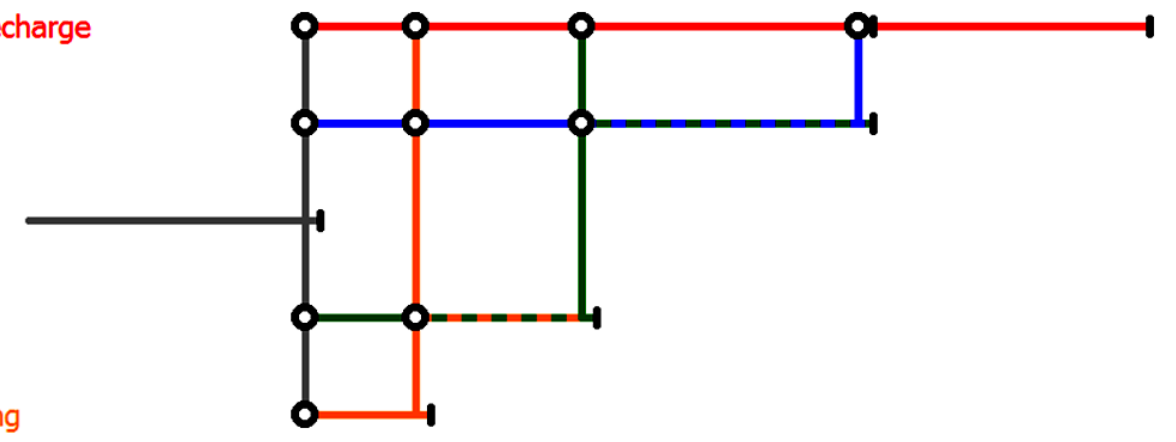

0

Land zoning

Saline resistant horticulture

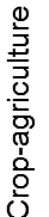

Current Situation

Arable field management

Alternate cropping/Crop diversification

Adaptive agriculture

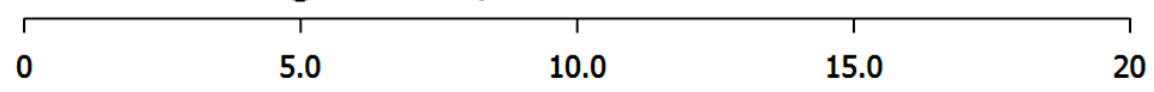

Ganges Barrage

Tidal river management

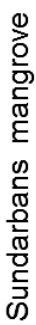

Gorai river restoration

Current Situation

Ban catching fish during breeding season

Cannals (re)- excavation

Strenghten BFD

Mass Awareness

ATP in salinity (ppt)

\begin{tabular}{lllll}
\hline 0 & 1 & 1 & & \\
& 5.0 & 10.0 & 15.0 & 20
\end{tabular}


farming. Shrimp farmers transport salt water through narrow channels from the rivers and the development of earthen embankments on the rivers. Leasing the khash lands for shrimp farming is thus increasing transport of saline water from the rivers to more area inland. Therefore, as a short-term measure, local people suggested limiting the leasing of the khash lands to the shrimp farmers. Also better planned and regulated shrimp farming can be a suitable measure to reduce the conflict with cropagriculture. In the long term, changed leasing systems and better planning may not be able to resist extensive shrimp farming. Therefore, improved regulations that follow natural salinity gradients, and coastal land use zone planning are needed. Improved coastal zone management should clearly outline the space for the conflicting sectors such as fresh water resources, shrimp, agriculture, and forestry.

Land zoning was also identified as the most suitable long-term measure by experts to strengthen crop-agriculture. Other potential measures such as crop diversification, adaptive agriculture, alternate cropping, and arable field management are currently implemented locally to adapt to moderate salt water intrusion. However, these adaptive agriculture measures will not be sufficient if the main pressure on the whole agriculture system, i.e., shrimp farming, is not addressed (Swapan and Gavin 2011), and at high levels of future salt intrusion, crop systems will continue to disappear. Hence, coastal land zoning that considers the natural salinity gradients and local land suitability in terms of hydro-climatic variables and socioeconomic conditions for different land uses is likely the most suitable adaptation measure to promote both crop-agriculture and shrimp farming.

Local people suggested to use khash lands for storing fresh water during the monsoon to deal with reduced upstream flow, instead of using the increasingly saline water for shrimp farming. This is probably a suitable measure for fresh water sources and agriculture during the dry season. However, the continuously increasing land demand by the increasing population challenges the implementation of this measure Therefore, key informants want to actively negotiate the transboundary process of water sharing as a more suitable immediate measure. However, previous records do show little progress in these negotiations (Morton 2011). Therefore, water sharing is probably a poor option because of a highly uncertain outcome. Other options, like upstream water management strategies for the dry season, administrative unit wide assessments on water demand, water budgets, and water allocation plans, can be developed but are currently too immature for implementation. Main uncertainties involve population growth and land demand, flash floods during monsoons and upstream agricultural water demand during the dry seasons. The Ganges barrage is the most suitable long-term measure to increase fresh water flow into the southwest, and therefore, increase freshwater resources availability and reduce salinization in the Sundarbans. Reduced upstream flow is the major cause for salinity increase in the Sundarbans mangrove (Bhuiyan and Dutta 2012) and a Ganges barrage could probably solve this. However, such barrage is very costly and also has several negative impacts. For instance, it will submerge a large area. This will make people's livelihoods vulnerable if proper replacements are not arranged.

Moreover, the adaptation pathways also suggest a range of measures to ensure long-term adaptation of the Sundarbans mangrove forest to future climate change. To improve the sustainable use and management of the forest, improved awareness raising and training of forest department staff is needed. However, to save the forest ensuring increased freshwater flow into the system is necessary to reduce salinity increase. Periodic (re)-excavation to restore the Gorai River can potentially increase the freshwater inflow. However, continuous (re)excavation may not be an economically viable measure in the longterm sustainability. Therefore, large scale tidal river management is proposed to ensure the connection of the rivers to the flood plain and to restore the natural process of land formation through sedimentation. This aims to reduce river bed siltation, waterlogging, and the effects of tidal water-level rise on the Sundarbans mangrove. This measure is highly likely to not only protect the Sundarbans against salinization but also stimulate crop-agriculture and fresh water sources. Such management is actually periodically cutting and closing polders, developed by local people to reduce drainage congestion induced by the polders (Hossain et al. 2015). It has been successfully implemented locally in the Hari River basin in the southern part of Jessore district for land reclamation (Paul et al. 2013). Shampa and Paramnik (2012) also suggested this socially acceptable and low cost ecotechnique to mitigate waterlogging problems in the Kobadak River basin area of Satkhira district. Also the multicriteria analysis shows that the measure is highly effective and feasible because it has low cost and negative side effects. The only challenge of this measure is the large-scale implementation and identification of the proper flood plains (locally called beels) for the tidal water inflow. Although it is a people-oriented approach, a good coordination among local stakeholders, government, and nongovernment entities is needed to overcome the challenges of large-scale implementation and long-term sustainability.

The methodology adopted in this study to develop adaptation pathways is a combination of different approaches with each approach having its own purpose. During our literature review, we identified that previous adaptive measures in the southwest coast of Bangladesh pressured the system backwards. One of the main reasons for this is probably the top-down decision-making approach (Fraser et al. 2006). Therefore, to fill this knowledge gap we surveyed local people to study their perception complemented with key informant interviews. This part of our study integrates both top-down and bottom-up observations. Although we did not receive adequate feedback from the household-level respondents on the long-term measures and potential adaptation turning points, they provided valuable information on the local socioeconomic processes of salinity increase and suggestions to address those. This information was incorporated in the DPSIR framework and also considered in the identification of potential measures to address the observed causes of salinity increase in addition to the key informants' perceptions. Besides, local people's perception on causes of salinity increase and suggestions to address those causes were taken into account during developing adaptation pathways. For instance, unplanned and extensive shrimp farming identified as the key cause of inland salinization and main pressure for the crop-agriculture system by the local people, can be tackled through land use zoning.

The identified interconnected climatic-social-ecological-economic causes of salinization are similar for all coastal systems. However, 
to address each of the causes, different measures are needed. For instance, an upstream barrage can be a potential option to address reduced freshwater influx while land zoning can control extensive shrimp farming, and tidal river management can reduce waterlogging and river bed siltation. All these measures contribute to adaptation. Hence at large scales, a combination of different measures helps to enhance resilience to salinization, however, at local scales different measures are more suitable for the different coastal systems. For example, Sundarbans mangrove is surrounded by the wetlands that are connected to the Bay of Bengal, coastal inlands, and upstream river networks. Therefore, reduced fresh water influx and tidal water-level rise are the major concerns for salinization in the Sundarbans. Conversely shrimp farming, waterlogging, and river bed siltation currently are the major concerns for crop-agriculture systems. Therefore, we developed three different adaptation pathways for the three most affected coastal systems. However, it is important to acknowledge that all systems are connected and intervention in one system will have impacts on the other systems as well.

Qualitative, i.e., multicriteria analysis, and quantitative, i.e., adaptation turning points, assessment to identify the potential adaptation measures and develop the adaptation pathway consequently, were based on the perceptions and observations of the key informants and local people. Hence, the adaptation turning points, suggested for each of the measures, may not be precise because we did not test the measures. However, it indicated a salinity range when shifting or adding another measure is necessary. The adaptation turning points can be improved through multiple climate model projections and calculation uncertainties ranges to develop more robust adaptation pathways (Tanaka et al. 2015). However, when using models, the number of measures that can be tested, are often limited. The developed adaptation pathways in our study included a large set of measures, which can be implemented at different salinity levels. This study, therefore, is a valuable first step in merging the top down and bottom up perceptions, in developing the DPSIR framework for salinity increase and adaptation pathways to cope with salinization.

\section{CONCLUSIONS}

The southwest coastal region of Bangladesh consists of complex, interacting, dynamic ecological and social systems. Hence, adaptation planning to cope with salinization is a complex endeavor for this region. The identified salinization pressures and impacts result from a series of systemic interactions in coastal environments at small- and large-scale processes. At larger scales, sea-level rise and reduced upstream flows are causing increased salinity while at local scales land use change, polders, and siltation are contributing. Increased salinity is affecting different socialecological-economic systems. It reduces crop production, affects drinking water resources, and biodiversity of the Sundarbans mangrove. The diverse causes of salt intrusion in combination with different systems it affects ask for a wide range of adaptation measures. This study also reveals that if the societal value of the coastal environment that supports life and livelihood of many coastal communities is ignored during adaptation planning, salinization likely gives rise to severe ecological, economic, and social problems and conflicts. To show how different measures can be used to adapt to different severities of salinity, three different adaptation pathways were developed giving a clear perspective for policy makers on how to plan for adaptation. Our adaptation pathways consider both the societal values and topdown perceptions, which suggest land zoning, managed aquifer recharge, and tidal river management to sustain at high salinity concentrations for crop-agriculture, fresh water sources, and the Sundarbans mangrove. Because different potential adaptive measures of the developed adaptation pathways for different coastal systems interrelate, the combined action is needed to ensure greater long-term benefits for the studied region.

Responses to this article can be read online at: http://www.ecologyandsociety.org/issues/responses. $\mathrm{php} / 10215$

\section{Acknowledgments:}

This study was made possible by a grant from Nuffic under the NFP fellowship programme (NFP-PhD.12/307). We would like to thank all the key informants and local people who provided valuable information for this work. We are grateful to all who helped in conducting interviews and surveys, especially Abdullah Al Masud, Khulna University; Engineer Peerzada Ibna Far Madani, Khulna University of Engineering and Technology; Siddikur Rahman Rana, Wageningen University; and Md. Aziz Ullah Emon, Chittagong University.

\section{LITERATURE CITED}

Abedin, M. A., U. Habiba, and R. Shaw. 2014. Community perception and adaptation to safe drinking water scarcity: salinity, arsenic, and drought risks in coastal Bangladesh. International Journal of Disaster Risk Science 5:110-124. http://dx.doi. org/10.1007/s13753-014-0021-6

Ayers, J. M., S. Huq, A. M. Faisal, and S. T. Hussain. 2014. Mainstreaming climate change adaptation into development: a case study of Bangladesh. Climate Change 5(1):37-51. http://dx. doi.org/10.1002/wcc.226

Bhuiyan, M. J. A. N., and D. Dutta. 2012. Assessing impacts of sea level rise on river salinity in the Gorai river network, Bangladesh. Estuarine, Coastal and Shelf Science 96:219-227. http://dx.doi.org/10.1016/j.ecss.2011.11.005

Bosomworth, K., A. Harwood, P. Leith, and P. Wallis. 2015. Adaptation pathways: a playbook for developing options for climate change adaptation in natural resource management. Southern Slopes Climate Change Adaptation. Research Partnership (SCARP): RMIT University, University of Tasmania, and Monash University, Melbourne, Australia.

Chowdhury, K. R. 2009. Tidal river plan could allay climate threat in southwest. bdnews24.com, 06 September. [online] URL: http:// bdnews24.com/bangladesh/2009/09/06/tidal-river-plan-could-allayclimate-threat-in-southwest

Dessai, S., and J. van der Sluijs. 2008. Uncertainty and climate change adaptation: a scoping study. Copernicus Institute for Sustainable Development and Innovation, Utrecht University, The Netherlands. 
Dillon, P. J., P. Pavelic, D. Page, H. Beringen, and J. Ward. 2009. Managed aquifer recharge. An introduction. Waterlines Report Series No. 13. National Water Commission, Canberra, Australia.

El Barmelgy, I. M., and S. E. A. Rasheed. 2016. Sustainable coastal cities between theory and practice (case study: Egyptian coastal cities). Journal of Sustainable Development 9(4):216. http://dx.doi.org/10.5539/jsd.v9n4p216

Fraser, E. D. G., A. J. Dougill, W. E. Mabee, M. Reed, and P. McAlpine. 2006. Bottom up and top down: analysis of participatory processes for sustainability indicator identification as a pathway to community empowerment and sustainable environmental management. Journal of Environmental Management 78(2):114-127. http://dx.doi.org/10.1016/j.jenvman.2005.04.009

Füssel, H.-M. 2007. Adaptation planning for climate change: concepts, assessment approaches, and key lessons. Sustainability Science 2(2):265-275. http://dx.doi.org/10.1007/s11625-007-0032$\mathrm{y}$

Haasnoot, M., J. H. Kwakkel, W. E. Walker, and J. ter Maat. 2013. Dynamic adaptive policy pathways: a method for crafting robust decisions for a deeply uncertain world. Global Environmental Change 23(2):485-498. http://dx.doi.org/10.1016/j.gloenvcha.2012.12.006

Haasnoot, M., W. P. A. Van Deursen, J. H. Guillaume, J. H. Kwakkel, E. Van Beek, and H. Middelkoop. 2014. Fit for purpose? Building and evaluating a fast, integrated model for exploring water policy pathways. Environmental Modelling \& Software 60:99-120. http://dx.doi.org/10.1016/j.envsoft.2014.05.020

Hossain, F., Z. H. Khan, and C. K. Shum. 2015. Tidal river management in Bangladesh. Nature Climate Change 5(6):492. http://dx.doi.org/10.1038/nclimate2618

Huq, N., J. Hugé, E. Boon, and A. K. Gain. 2015. Climate change impacts in agricultural communities in rural areas of coastal Bangladesh: a tale of many stories. Sustainability 7(7):8437-8460. http://dx.doi.org/10.3390/su7078437

Khan, A. E., A. Ireson, S. Kovats, S. K. Mojumder, A. Khusru, A. Rahman, and P. Vineis. 2011. Drinking water salinity and maternal health in coastal Bangladesh: implications of climate change. Environmental Health Perspectives 119(9):1328-1332. http://dx.doi.org/10.1289/ehp.1002804

Khanom, T. 2016. Effect of salinity on food security in the context of interior coast of Bangladesh. Ocean \& Coastal Management 130:205-212. http://dx.doi.org/10.1016/j.ocecoaman.2016.06.013

Mahmuduzzaman, M., Z. U. Ahmed, A. K. M. Nuruzzaman, and F. R. S. Ahmed. 2014. Causes of salinity intrusion in coastal belt of Bangladesh. International Journal of Plant Research 4 (4A):8-13.

Mirza, M. M. Q. 1998. Diversion of the Ganges water at Farakka and its effects on salinity in Bangladesh. Environmental Management 22(5):711-722. http://dx.doi.org/10.1007/s002679900141

Morton, K. 2011. Climate change and security at the third pole. Survival 53(1):121-132. http://dx.doi.org/10.1080/00396338.2011.555606

Nandy, P., R. Ahammad, M. Alam, and A. Islam. 2013. Coastal ecosystem based adaptation: Bangladesh experience. Pages 277-303 in R. Shaw, F. Mallick, and A. Islam, editors. Climate change adaptation actions in Bangladesh. Springer, Tokyo, Japan. http://dx.doi.org/10.1007/978-4-431-54249-0_15

Nicholls, R. J., and A. Cazenave. 2010. Sea-level rise and its impact on coastal zones. Science 328(5985):1517-1520. http://dx.doi. org/10.1126/science. 1185782

Nowreen, S., M. R. Jalal, and M. S. A. Khan. 2014. Historical analysis of rationalizing South West coastal polders of Bangladesh. Water Policy 16(2):264-279. http://dx.doi.org/10.2166/ wp.2013.172

Paul, A., B. Nath, and M. R. Abbas. 2013. Tidal river management (TRM) and its implication in disaster management: a geospatial study on Hari-Teka river basin, Jessore, Bangladesh. International Journal of Geomatics and Geosciences 4(1):125.

Penning-Rowsell, E. C., P. Sultana, and P. M. Thompson. 2013. The 'last resort'? Population movement in response to climaterelated hazards in Bangladesh. Environmental Science \& Policy 27:S44-S59. http://dx.doi.org/10.1016/j.envsci.2012.03.009

Pinto, R., V. N. de Jonge, J. M. Neto, T. Domingos, J. C. Marques, and J. Patrício. 2013. Towards a DPSIR driven integration of ecological value, water uses and ecosystem services for estuarine systems. Ocean \& Coastal Management 72:64-79. http://dx.doi. org/10.1016/j.ocecoaman.2011.06.016

Rabbani, G., S. H. Rahman, and L. Faulkner. 2013. Impacts of climatic hazards on the small wetland ecosystems (ponds): evidence from some selected areas of coastal Bangladesh. Sustainability 5(4):1510-1521. http://dx.doi.org/10.3390/su5041510

Rahman, M. A., and S. Rahman. 2015. Natural and traditional defense mechanisms to reduce climate risks in coastal zones of Bangladesh. Weather and Climate Extremes 7:84-95. http://dx. doi.org/10.1016/j.wace.2014.12.004

Rasel, H. M., M. R. Hasan, B. Ahmed, and M. S. U. Miah. 2013. Investigation of soil and water salinity, its effect on crop production and adaptation strategy. International Journal of Water Resources and Environmental Engineering 5(8):475-481.

Renaud, F. G., T. T. H. Le, C. Lindener, V. T. Guong, and Z. Sebesvari. 2015. Resilience and shifts in agro-ecosystems facing increasing sea-level rise and salinity intrusion in Ben Tre Province, Mekong Delta. Climatic Change 133(1):69-84. http://dx.doi. org/10.1007/s10584-014-1113-4

Sarker, S. K., R. Reeve, J. Thompson, N. K. Paul, and J. Matthiopoulos. 2016. Are we failing to protect threatened mangroves in the Sundarbans world heritage ecosystem? Scientific Reports 6:21234. http://dx.doi.org/10.1038/srep21234

Shampa, M. I. M. P., and M. Paramanik. 2012. Tidal river management (TRM) for selected coastal area of Bangladesh to mitigate drainage congestion. International Journal of Scientific and Technology Research 1.

Smeets, E., and R. Weterings. 1999. Environmental indicators: typology and overview Technical report No. 25. European Environment Agency, Copenhagen, Denmark.

Soil Resource Development Institute (SRDI). 2010. Saline soils of Bangladesh. SRDI, Ministry of Agriculture, Government of Bangladesh, Dhaka, Bangladesh. 
Swapan, M. S. H., and M. Gavin. 2011. A desert in the delta: participatory assessment of changing livelihoods induced by commercial shrimp farming in Bangladesh. Ocean \& Coastal Management 54(1):45-54. http://dx.doi.org/10.1016/j.

ocecoaman.2010.10.011

Tanaka, A., K. Takahashi, Y. Masutomi, N. Hanasaki, Y. Hijioka, H. Shiogama, and Y. Yamanaka. 2015. Adaptation pathways of global wheat production: importance of strategic adaptation to climate change. Scientific Reports 5:14312. http://dx.doi. org/10.1038/srep14312

Water Resources Planning Organization (WARPO). 2001. National water management plan (NWMP), Volume 2: Main report. WARPO, Ministry of Water Resources, Dhaka, Bangladesh.

Werners, S. E., S. Pfenninger, E. van Slobbe, M. Haasnoot, J. H. Kwakkel, and R. J. Swart. 2013. Thresholds, tipping and turning points for sustainability under climate change. Current Opinion in Environmental Sustainability 5(3-4):334-340. http://dx.doi. org/10.1016/j.cosust.2013.06.005

Wise, R. M., I. Fazey, M. Stafford Smith, S. E. Park, H. C. Eakin, E. R. M. A. Van Garderen, and B. Campbell. 2014. Reconceptualising adaptation to climate change as part of pathways of change and response. Global Environmental Change 28:325-336. http://dx.doi.org/10.1016/j.gloenvcha.2013.12.002 
Appendix 1. Multicriteria analysis of the potential measures recommended by the household level respondents to address the perceived causes of salinity increase

\begin{tabular}{|c|c|c|c|c|c|c|c|}
\hline \multirow[b]{2}{*}{$\begin{array}{l}\text { Sl. } \\
\text { No. }\end{array}$} & \multirow[b]{2}{*}{ Potential measures } & \multicolumn{5}{|l|}{ Criteria $^{*}$} & \multirow[b]{2}{*}{ Score } \\
\hline & & Effectiveness & $\begin{array}{l}\text { Side } \\
\text { effects }\end{array}$ & Cost & Feasibility & Uncertainty & \\
\hline 1 & Limit shrimp farming practice & +++ & +++ & +++ & + & + & 11 \\
\hline 2 & $\begin{array}{l}\text { Local government's initiative to prevent on } \\
\text { purpose ingression of salt water }\end{array}$ & +++ & +++ & +++ & ++ & + & 12 \\
\hline 3 & $\begin{array}{l}\text { Outlaw building unnecessary dams on the } \\
\text { rivers }\end{array}$ & ++ & +++ & +++ & ++ & + & 11 \\
\hline 4 & $\begin{array}{l}\text { Operational sluice gates of the existing } \\
\text { polders }\end{array}$ & ++ & +++ & - & ++ & + & 7 \\
\hline 5 & (Re)-Excavation of the silted rivers & +++ & +++ & -- & +++ & - & 6 \\
\hline 6 & Riverbank protection & +++ & +++ & --- & +++ & - & 5 \\
\hline 7 & $\begin{array}{l}\text { Government initiative to change the leasing } \\
\text { system and the use of Khash lands }\end{array}$ & ++ & +++ & +++ & + & + & 10 \\
\hline
\end{tabular}

*For description with score card for the selected criteria please see Table 1 
Appendix 2. Multicriteria analysis of potential set of measures recommended by the key informants to address the observed causes of salinity increase

\begin{tabular}{|c|c|c|c|c|c|c|c|c|}
\hline \multirow{2}{*}{$\begin{array}{l}\text { Sl. } \\
\text { No. }\end{array}$} & \multirow{2}{*}{\multicolumn{2}{|c|}{ Potential measures }} & \multicolumn{5}{|l|}{ Criteria $^{*}$} & \multirow[b]{2}{*}{ Score } \\
\hline & & & Effectiveness & $\begin{array}{l}\text { Side } \\
\text { effects }\end{array}$ & Cost & Feasibility & Uncertainty & \\
\hline 1. & \multirow{6}{*}{$\begin{array}{l}\text { Short } \\
\text { term }\end{array}$} & Planned shrimp farming practice & +++ & +++ & +++ & ++ & +++ & 14 \\
\hline 2. & & $\begin{array}{l}\text { Functional management of the } \\
\text { existing polders }\end{array}$ & +++ & +++ & - & ++ & - & 6 \\
\hline 4. & & Periodic/scheduled (re)-excavation & +++ & +++ & -- & ++ & - & 5 \\
\hline 5. & & $\begin{array}{l}\text { Strengthen and heighten the existing } \\
\text { embankments }\end{array}$ & ++ & ++ & - & + & - & \\
\hline 6. & & $\begin{array}{l}\text { Reduce dependency on ground water } \\
\text { extraction for upstream irrigation }\end{array}$ & + & +++ & - & + & -- & 2 \\
\hline 7. & & $\begin{array}{l}\text { To be active in transboundary } \\
\text { negotiation process on water sharing }\end{array}$ & + & +++ & + & + & --- & 3 \\
\hline 8. & \multirow{6}{*}{$\begin{array}{l}\text { Mid- } \\
\text { term }\end{array}$} & Designing land management practice & ++ & +++ & - & ++ & - & 5 \\
\hline 9 & & $\begin{array}{l}\text { Planned infrastructural development } \\
\text { in water resource management }\end{array}$ & +++ & +++ & --- & +++ & - & 5 \\
\hline 10. & & $\begin{array}{l}\text { TRM along with sediment } \\
\text { management practice }\end{array}$ & +++ & +++ & +++ & ++ & +++ & 14 \\
\hline 11. & & $\begin{array}{l}\text { Administrative unit wise assessment } \\
\text { on demand of water for different } \\
\text { category enforcement of Water Act } \\
2013 \text { on priority basis; }\end{array}$ & ++ & +++ & - & ++ & - & 5 \\
\hline 12. & & $\begin{array}{l}\text { Develop upstream water management } \\
\text { strategy for dry season }\end{array}$ & + & +++ & - & + & - & 3 \\
\hline 13. & & $\begin{array}{l}\text { Enforcement of Water Act } 2013 \text { on } \\
\text { priority basis }\end{array}$ & ++ & +++ & -- & + & + & 5 \\
\hline 14. & \multirow{6}{*}{$\begin{array}{l}\text { Long } \\
\text { term }\end{array}$} & Land use zoning & +++ & +++ & + & +++ & + & 11 \\
\hline 15. & & $\begin{array}{l}\text { Integrated management of different } \\
\text { systems }\end{array}$ & ++ & ++ & -- & ++ & - & 3 \\
\hline 16. & & $\begin{array}{l}\text { Continuous monitoring on river flow } \\
\text { and sedimentation rate }\end{array}$ & +++ & +++ & --- & +++ & - & 5 \\
\hline 17. & & $\begin{array}{l}\text { Delta plan/Integrated long term plan } \\
\text { for the coast }\end{array}$ & +++ & +++ & -- & +++ & + & 8 \\
\hline 18. & & Water budget and allocation plan & ++ & +++ & -- & ++ & + & 6 \\
\hline 19. & & Ganges barrage & +++ & +++ & --- & +++ & + & 7 \\
\hline
\end{tabular}

*For description with score card for the selected criteria please see Table 1 
Appendix 3. Potential set of measures and their contribution recommended by the key informants for the most affected coastal systems

\begin{tabular}{|c|c|c|c|c|}
\hline \multirow{2}{*}{$\begin{array}{l}\text { Mostly affected coastal } \\
\text { systems }\end{array}$} & \multicolumn{3}{|c|}{ Potential measures along with the score from multi-criteria analysis in (.. ) and Adaptation turning point (ATP) } & \multirow{2}{*}{ Expected Contribution } \\
\hline & ATP (7-12ppt) & ATP (15-17ppt) & ATP $(\geq 20 \mathrm{ppt})$ & \\
\hline Crop Agriculture & 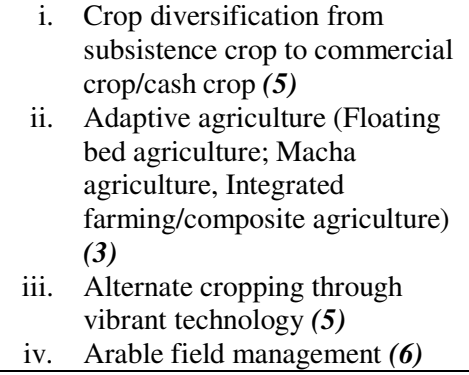 & $\begin{array}{l}\text { i. Genetically modified salt } \\
\text { tolerant crop (2) } \\
\text { ii. Saline resistant horticulture (6) }\end{array}$ & $\begin{array}{l}\text { i. Alternative Income Generation } \\
\text { (AIG) activities and micro } \\
\text { finance (2) } \\
\text { ii. Land zoning (7) }\end{array}$ & $\begin{array}{l}\text { - Promote agriculture; } \\
\text { - Uplift socio-economic status of the } \\
\text { farmers; } \\
\text { - Reduce the direct conflict of crop } \\
\text { agriculture with shrimp agriculture; }\end{array}$ \\
\hline Drinking water sources & $\begin{aligned} \text { i. } & \text { Rain water harvesting (7) } \\
\text { ii. } & \text { Pond excavation (7) }\end{aligned}$ & $\begin{aligned} \text { i. } & \text { Pond sand filter (5) } \\
\text { ii. } & \text { Desalinization plant (2) }\end{aligned}$ & $\begin{aligned} \text { i. } & \text { Permanent storage for monsoon } \\
& \text { water (2) } \\
\text { ii. } & \begin{array}{l}\text { Managed Aquifer Recharge } \\
\text { (MAR) (6) }\end{array} \\
\text { iii. } & \text { Pond Technology (2) }\end{aligned}$ & $\begin{array}{l}\text { - Reduce the scarcity of drinking water; } \\
\text { - Contribute in health issues; }\end{array}$ \\
\hline Sundarbans Mangrove & $\begin{array}{ll}\text { i. } & \text { Mass awareness }(8) \\
\text { ii. } & \text { Ban catching fish during the } \\
\text { breeding season }(8) \\
\text { iii. } \\
\text { iv. } \\
\text { v. Canals (re)-excavation (6) } \\
\text { v. Gorai river restoration (5) } \\
\text { vi. Develop water diplomacy (Re- } \\
\text { negotiation for Ganges water } \\
\text { sharing and Teesta agreement) } \\
\text { (4) }\end{array}$ & $\begin{array}{ll}\text { i. } & \text { Captive breeding of } \\
\text { vulnerable/threatened species } \\
\text { (3) } \\
\text { ii. Livelihood diversification (3) } \\
\text { iii. Tidal River Management (14) }\end{array}$ & $\begin{array}{l}\text { i. Regional and Global Co- } \\
\text { operation (3) } \\
\text { ii. Ganges Barrage (7) } \\
\text { iii. Water reservoirs in the upstream } \\
\text { (at Modhumati / Gorai) (1) }\end{array}$ & $\begin{array}{l}\text { - Ensure lean period upstream water sharing; } \\
\text { - Reduce extraction of the forest resources; } \\
\text { - Reduce local people's dependency } \\
\text { - Lessen the external disturbance (human } \\
\text { interference) on the natural systems; } \\
\text { - Promote in-situ conservation; } \\
\text { - Control Snaring and rampant Poaching; } \\
\text { - Support the fishery resources in } \\
\text { Sundarbans; } \\
\text { - Quantify the resource extraction scenario; } \\
\text { - Ensure Thousands of ecosystem services; } \\
\text { - Identification of the research gaps and } \\
\text { more research; } \\
\text { - Ensure eco-flow of water; } \\
\text { - Reduce much intervention and } \\
\text { participatory management ; }\end{array}$ \\
\hline
\end{tabular}


Appendix 4. An example to facilitate interpretation of an adaptation pathway map to cope with salinization

The adaptation pathway map

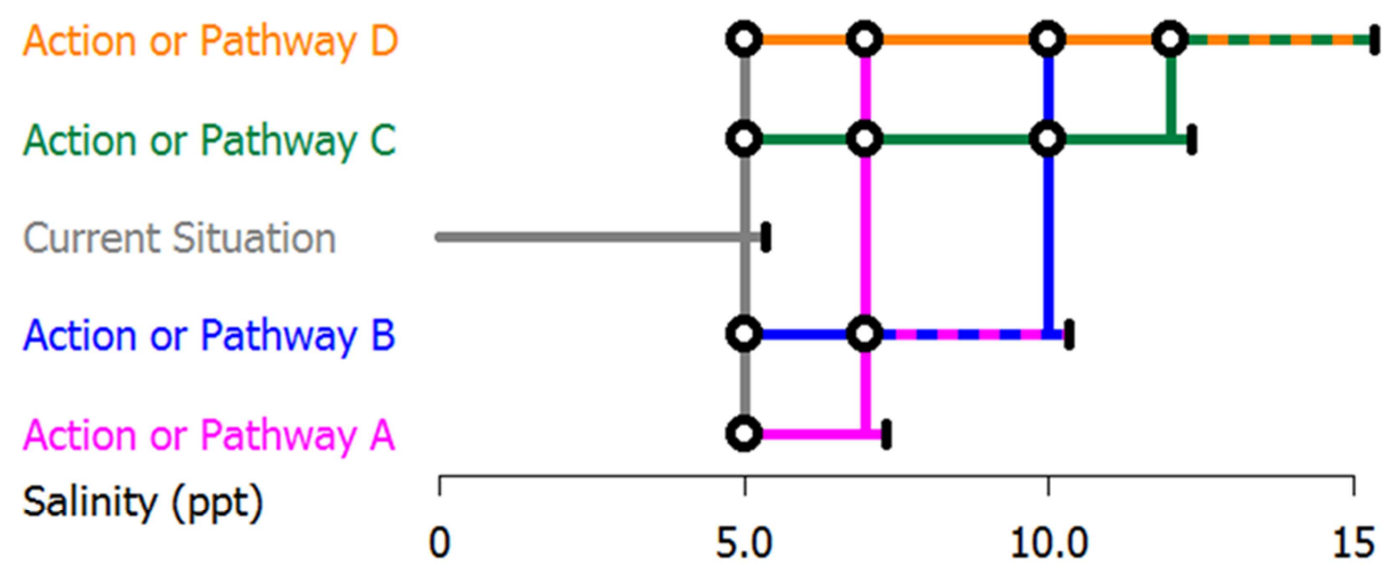

0 Transfer station to new action I Adaptation tipping point (ATP) of an action - Adaptation pathways

How to interpret the map

Action or Pathway A can sustain up to salinity level 7ppt while the Action or Pathway B in combination with A will sustain till 10ppt of salinity. If salinity level crosses 10ppt, Action or pathway $\mathrm{C}$ is the most suitable measure until the salinity level goes beyond $12 \mathrm{ppt}$. Finally the Action or pathway D combined with Action C are expected to sustain up to $15 \mathrm{ppt}$ of salinity. 